\title{
Three globalizations, not two: rethinking the history and economics of trade and globalization
}

\author{
Thomas I. Palley* \\ Independent Economist, Washington, DC, USA
}

The conventional wisdom is that there have been two globalizations in the modern era. The first began around 1870 and ended in 1914. The second began in 1945 and is still under way. This paper challenges that view and argues that there have been three globalizations, not two. The first half of the paper provides empirical evidence for the three-globalizations hypothesis. The second half discusses its analytical implications. The Victorian first globalization and the Keynesian-era second globalization were driven by gains from trade, and those gains increased industrialized country real wages. The neoliberal third globalization has been driven by industrial reorganization motivated by distributional conflict. Trade theory does not explain the third globalization; capital's share has increased at the expense of labor'; and there can be no presumption of mutually beneficial country gains from the third globalization.

Keywords: globalization, trade theory, barge economics

JEL codes: F0O, F10, F20

\section{CHALLENGING THE STYLIZED HISTORY OF GLOBALIZATION}

It is often said that the winners get to write history. Consequently, the causes and arguments of the losers are diminished and dismissed, while those of the winners are rationalized and approved. In economics, the same can be said of theory. Thus, economics textbooks reflect the dominant point of view, which in turn tends to reflect the dominant set of interests.

Economic history and economic theory come together in the form of 'stylized history,' which provides a simplified representation of a complex reality that is taken to be essentially true. Stylized history is carefully constructed to be consistent with the dominant theory, so that history and theory march arm-in-arm in the service of the winners.

Stylized history performs a vital double function. First, it constructs a simplified reality that is supportive of the dominant theory. Second, it provides a shield against empirical critique and inconvenient details.

The significance of stylized history is keenly present in mainstream economics' account of the history of globalization. That account holds that there have been two globalizations in the modern era. The first began around 1870 and ended in 1914, while the second began in 1945 and is still under way. That two-globalizations framing is used to keep at bay critical theoretical interpretations of the recent era of globalization.

This paper provides an alternative three-globalizations account of the history of the global economy over the past 150 years. The three-globalizations account dramatically transforms the interpretation of developments over the past 30 years. Instead of viewing those recent

* Email: mail@thomaspalley.com. 
developments through the lens of international trade, they are viewed through the lens of reconfiguring the global organization of production. The goal has been to redistribute income from labor to capital, and to enable business to escape the social and economic constraints that were imposed after the Great Depression and the failure of Victorian capitalism.

Analytically, the critical feature of the three-globalizations hypothesis is to sunder the identification of globalization with trade. Contemporary globalization is about the global reconfiguration of production, not trade. Trade is inevitably involved because goods and services must cross borders. However, the pattern of transactions is not explained by trade theory, which is about mutually beneficial exchange. Instead, it is explained by industrial reorganization motivated by distributional conflict, and aimed at increasing profitability and the profit share.

The new logic of trade has produced winners and losers. Winners include emerging market economies which have been recipients of large foreign direct investment inflows aimed at creating export production platforms. Owners of capital in developed countries have also been winners, but developed country labor has been a big loser. ${ }^{1}$ The important implication is that individual country and even global gains may be negative. That contrasts with conventional Hecksher-Ohlin trade theory (Stolper/Samuelson 1941) in which individual factors may lose but, absent unlikely pathologies, country and global gains are positive.

\section{THE TWO-GLOBALIZATIONS HYPOTHESIS OF MAINSTREAM ECONOMICS}

Figure 1 (overleaf) provides a graphical description of the history of global trade for the period 1870-2011, showing world exports and imports as a share of world GDP. The socalled first globalization is identified as beginning in 1870. It rested on the introduction of the telegraph, refrigeration, and significant improvements in steamship and railroad transportation. Together, these developments fueled a massive increase in trade between Western Europe and the global economy. Additionally, there was massive migration from Europe to North America, South America, South Africa, and Australasia.

The first globalization is claimed to have run from 1870 to 1914 , coming to an end with World War I. From 1870 through to 1913 there was a steady trend increase in global trade (it actually peaked in 1912). Trade then fell precipitously in 1914, but the fall was artificially reversed by Allied imports of food and war material in 1917 and 1918 .

Thereafter, global trade collapsed and trended down throughout the interwar period. There were cyclical recoveries in the 1920s and 1930s, but trade never recovered its prewar standing as a share of global GDP. The nadir was 1945, when global trade was just 10.2 percent of global GDP.

1. The cause of changed income distribution and increased income inequality in developed countries is multi-faceted and globalization is only one part of the story, albeit very important. Palley (2012) explains the change in terms of a neoliberal policy agenda that has pushed globalization, labor market flexibility, smaller government, and abandoning the commitment to full employment. After long denying the significance of globalization for US wages income inequality, mainstream economists are coming round to agreeing on its importance (for example, Autor et al. 2013). Bronfenbrenner (2000) and Bronfenbrenner/Luce (2004) provided early documentation of the adverse effects of the North American Free Trade Agreement (NAFTA) and China on US union manufacturing jobs and wages. Palley (1999) provided an early estimate of globalization on US income inequality, with globalization explaining 27 percent of the increase in the US Gini coefficient between 1980 and 1997. 


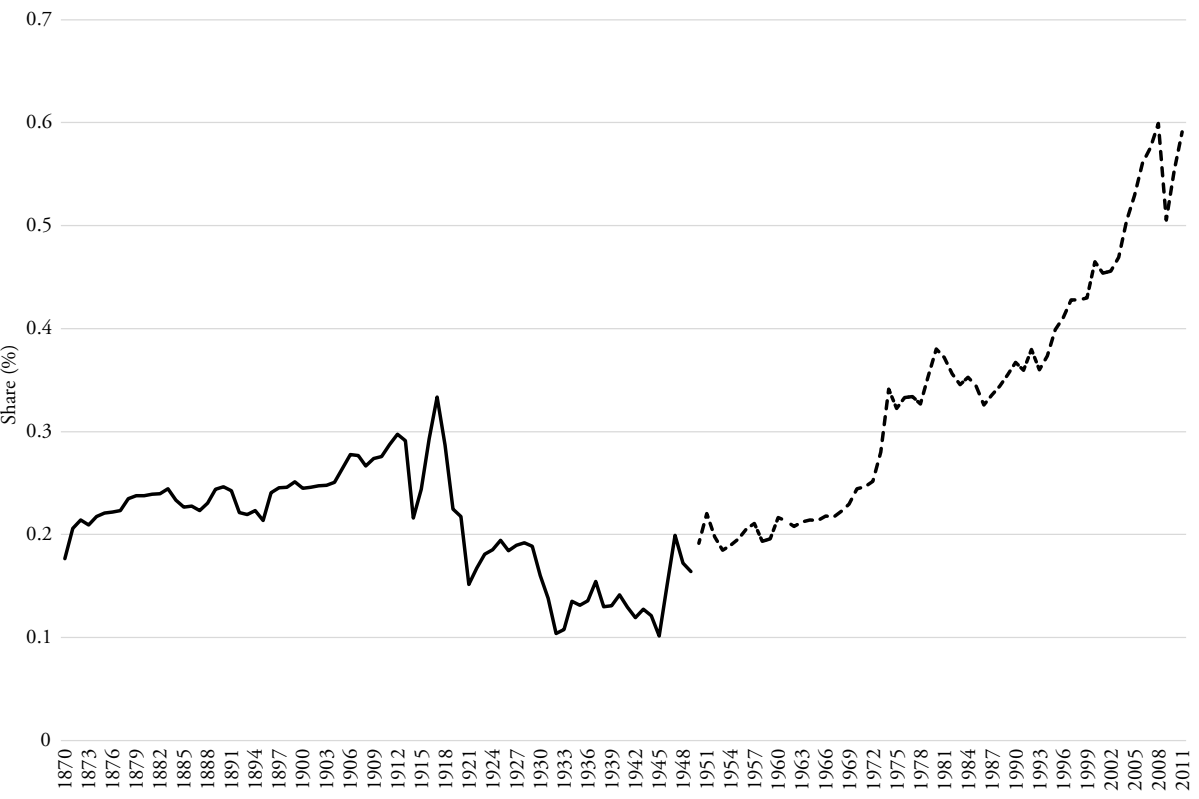

Source: Ortiz-Ospina/Roser (2017): 1870-1949 data from Klasing/Milionis (2014); 1950-2011 data from Penn World Tables 8.1.

Figure 1 The history of global trade: world exports and imports as a share of global GDP (\%), 1870-2011

The second globalization began in 1945, which marked the beginning of a persistent expansion of global trade. As regards details, there was a sharp recovery of trade in the late 1940 s, reflecting reconstruction of a peacetime global economy. There was a second sharp spurt in trade between 1968 and 1980, reflecting the commodity price booms and OPEC oil price shocks of that 12-year period which raised the value of trade relative to GDP. Lastly, there was a third spurt in trade after 1991, which lasted through to the financial crisis of 2008. In 2009, trade collapsed. It has since recovered, though it has not recovered its previous growth rate.

The history of the two globalizations is summarized in Table 1, which shows global trade as a share of global GDP for selected years. The first globalization ran from 1870 to 1914 . That was followed by a globalization inter-regnum that ran from the end of World War I to the end of World War II. The second globalization began in 1946 and continues. 1972 marked the end of the Bretton Woods era, but globalization continued and even accelerated.

There are two important features of the conventional two-globalizations hypothesis. First, globalization is identified with the history of trade, so that trade is globalization

Table 1 World exports and imports as a share of world GDP (\%)

\begin{tabular}{cccccc}
\hline 1870 & 1913 & 1938 & 1946 & 1972 & 2011 \\
\hline $17.7 \%$ & $29.1 \%$ & $13.0 \%$ & $15.1 \%$ & $25.2 \%$ & $59.1 \%$ \\
\hline
\end{tabular}

Source: Ortiz-Ospina/Roser (2017). 
and globalization is trade. Second, the narrative is constructed around an interwar interruption of globalization, which resumed after World War II. In a manner of speaking, that implies there has been only one globalization, which was temporarily put on hold in the 1920 s and 1930s.

\section{THE THREE-GLOBALIZATIONS HYPOTHESIS}

The three-globalizations hypothesis introduces a third globalization that began in 1990 and continues. The periodization of the first globalization is unchanged (1870-1914) and it is labeled the 'Victorian globalization.' The second globalization is shortened to the period 1945-1990 and it is labeled the 'Keynesian-era globalization.' The third globalization began around 1990 and it is labeled the 'neoliberal globalization.'

All discrete periodizations of history inevitably have an arbitrary element about them, but they can still be vitally useful as a taxonomy that facilitates seeing larger patterns. The three-globalizations hypothesis supplements the periodization of the two-globalizations hypothesis with an additional period that begins in 1990. Data presented in the paper show that there seems to have been a break in the character and pattern of global trade and investment around that time. At the symbolic level, 1990 marks the postwar reunification of Germany and the full and free entry of the former Soviet bloc economies into the global economy. Additionally, by 1990, negotiations were already well in train for the new trade and investment agreements (for example, NAFTA in 1994, the WTO founding in 1995) that now define the structure of the global economy. Those negotiations reflected economic developments getting under way, and the resulting agreements accelerated and deepened those developments rather than initiating them.

The three globalizations constitute a sedimentary process whereby new developments are added on top of prior developments, so that old patterns of trade remain and are supplemented by new ones. One implication is that there is no single explanation of trade, and different trade patterns coexist and each requires a different theoretical explanation.

Whereas the two-globalizations hypothesis is viewed through the lens of just trade 'volume,' the three-globalizations hypothesis adds the issue of trade 'composition.' Figure 2 (overleaf) shows the changing composition of trade from 1900 to 2011. A thumbnail sketch of developments is as follows. The Victorian first globalization was dominated by agricultural trade, with agricultural products constituting 57 percent of trade in 1900. The essential structure of Victorian globalization had the industrialized economies of Western Europe supplying manufactured goods to the emerging economies of Canada, the USA, Argentina, and Australasia, which supplied agricultural products in exchange.

The Keynesian-era second globalization saw a twist in the composition of trade. Victorian globalization trade continued, but it was supplemented by trade in manufactured goods between the industrialized economies of Western Europe, North America, and Japan. Toward the end of the period, other late industrializers (including Taiwan, South Korea, Hong Kong, and Singapore) joined in. In 1955, manufactured goods represented 55 percent of global trade measured as a share of GDP. By 1990, the manufactured share had risen to 70 percent. This new trade involved an exchange between industrialized countries of manufactured goods for manufactured goods.

This pattern of manufactures-for-manufactures trade is captured in Figure 3 (overleaf), which shows the evolution of global intra-industry trade for the period 1962-2006. Between 1962 and 1990, there was a steady increase in intra-industry trade (using both aggregate industry classifications and available detailed industry classifications). 
178 European Journal of Economics and Economic Policies: Intervention, Vol. 15 No. 2

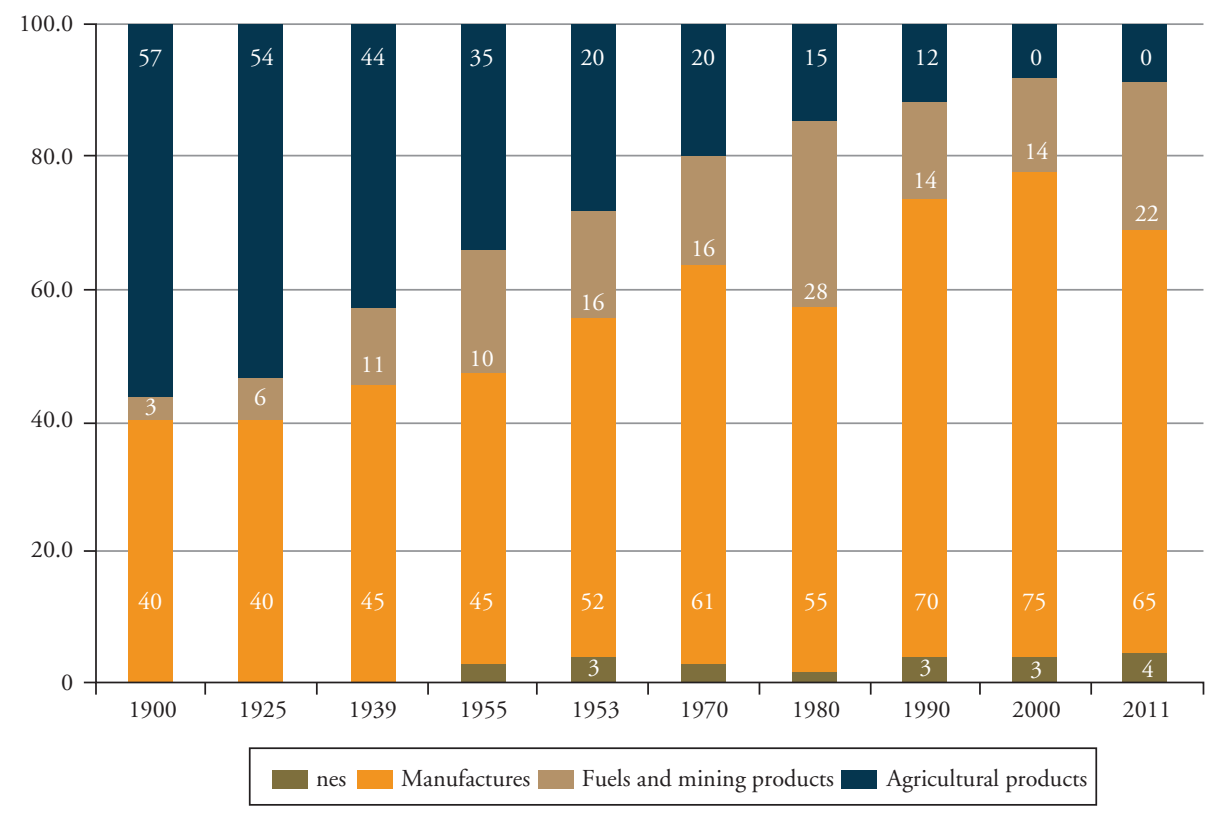

Source: WTO (2013: 54).

Figure 2 The changing composition of world trade

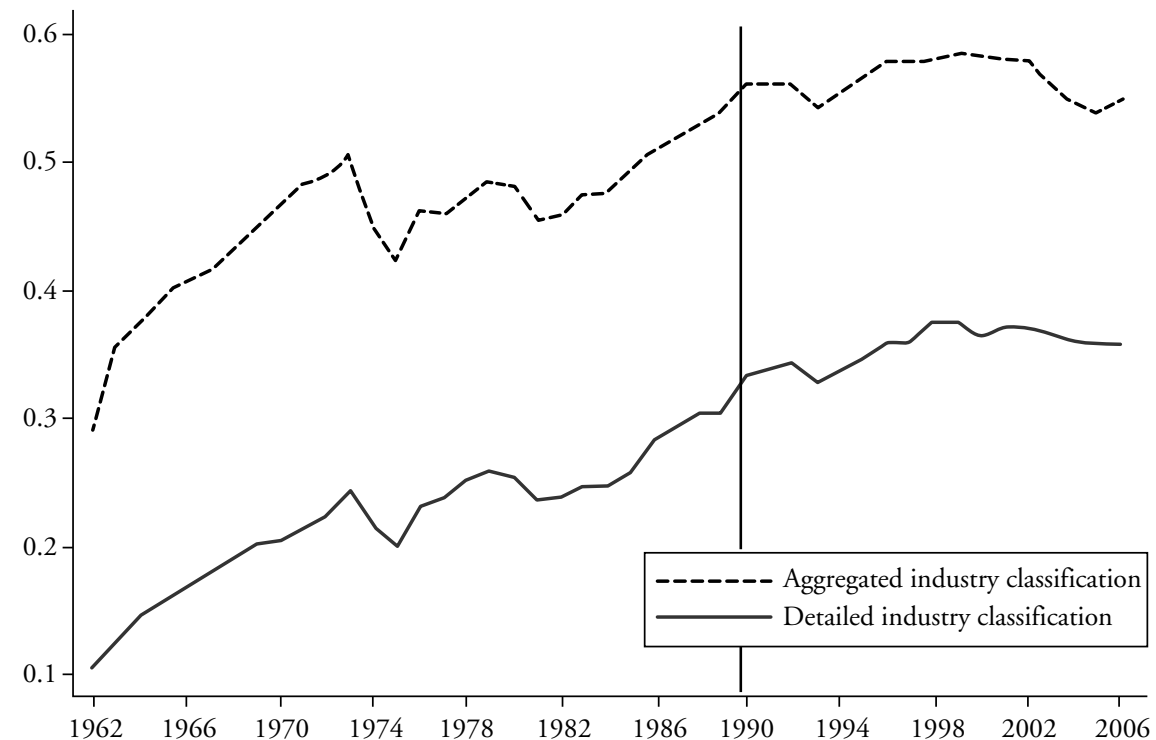

Source: Melitz/Trefler (2012).

Figure 3 World share of intra-industry trade, 1962-2006 
Table 2 Developing and transition economies' share of global GDP, global exports, and global imports, 1980-2015

\begin{tabular}{lcccccc}
\hline & 1980 & 1990 & 2000 & 2005 & 2010 & 2015 \\
\hline Share of global GDP (\%) & 30.4 & 21.3 & 22.9 & 25.9 & 36.3 & 43.2 \\
Share of global exports (\%) & 33.9 & 27.5 & 34.2 & 39.6 & 46.1 & 48.0 \\
Share of global imports (\%) & 28.0 & 26.0 & 30.2 & 34.0 & 42.0 & 44.3 \\
\hline
\end{tabular}

Source: UNCTAD (2016: tables 1.1 and 7.1).

The neoliberal third globalization begins in 1990. The new feature is a massive shift in the location of economic activity and trade, which in turn changes the geographic composition of trade. Figure 2 shows that the manufactures' trade share continues to hover around 70 percent. It was 70 percent in 1990 and 65 percent in 2011 . However, that small decline in 2011 likely reflects temporary displacement caused by the higher price of oil and commodities, as also happened in the 1980 period. Figure 3 shows the intra-industry share of global trade also remains relatively constant. The aggregate industry classification data show it hovering around 55 percent throughout the period 1990-2006.

In contrast, Table 2 shows the huge scale of the geographic shift of economic activity and trade during the neoliberal third globalization. There is an enormous increase in developing and transition economies' share of global GDP, global exports, and global imports over the period 1980-2015. Their share of global economic activity and trade fell during the tail-end of the Keynesian-era second globalization, but it has risen sharply and persistently throughout the neoliberal third globalization.

The driver of those shifts has been the shift of manufacturing activity from industrialized economies to developing economies. This is evident in Figure 4 which shows the distribution of world manufacturing for selected years over the past 250 years. The period 1980-2006 was marked by several features. First, there was a steep decline in the share of manufacturing in the former Soviet Union. Second, there was a large decline in the share of manufacturing in North America. Third, there was a large increase in the share of manufacturing in China,

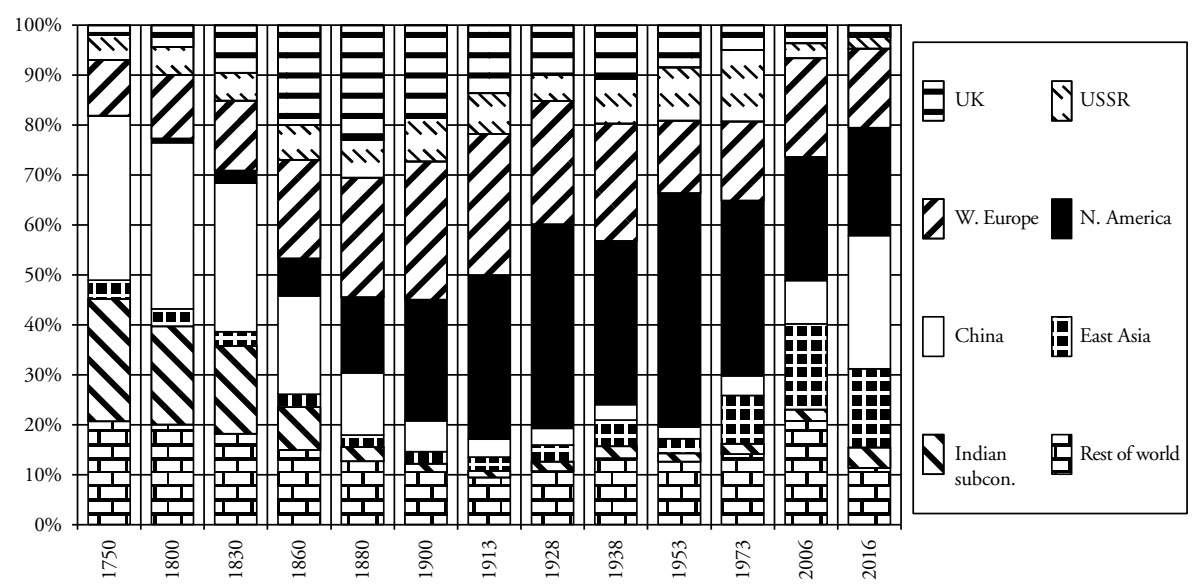

Source: Allen (2011: fig. 2).

\section{Figure 4 Distribution of world manufacturing}




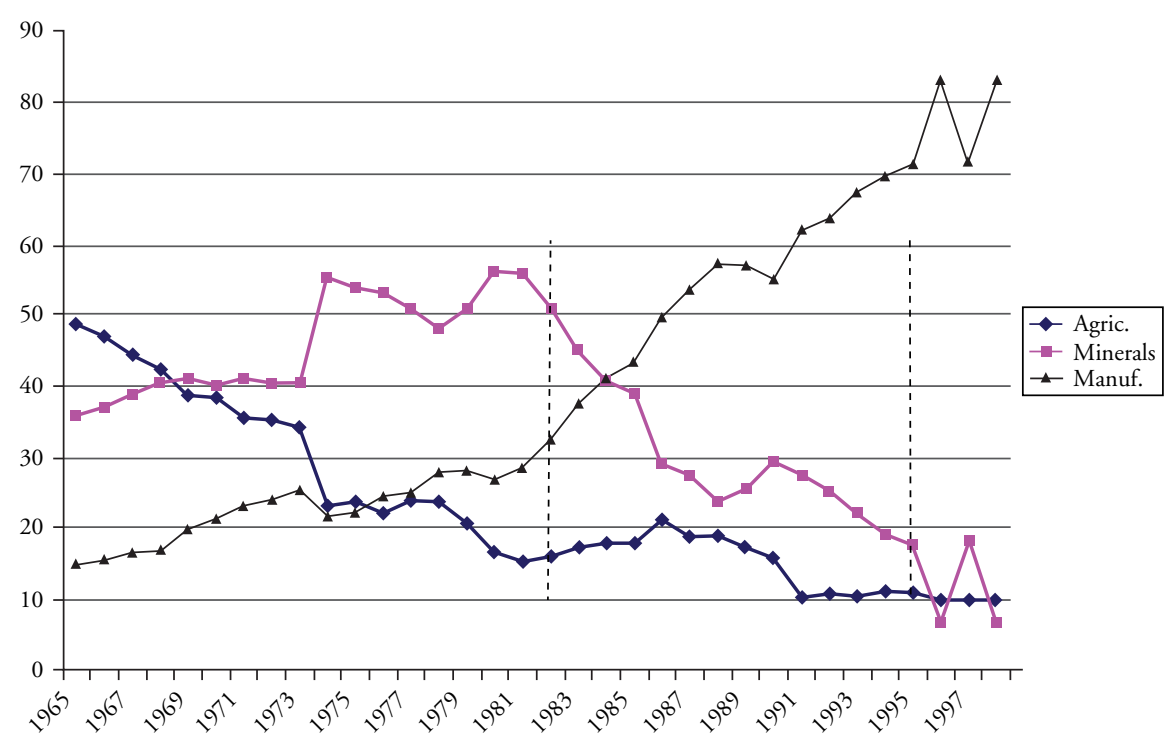

Source: Martin (2001).

Figure 5 Changing composition of developing country merchandise exports

East Asia, the Indian sub-continent, and the rest of the world (that is, the area below the solid black block). That group constitutes the developing economies. From 1953 to 1980 their share had increased marginally; after 1980, it spikes. In the space of 25 short years the distribution of global manufacturing was significantly reshaped. If the USSR were excluded from the data, the relative decline of the North American manufacturing share and the increase in the China-East Asia share would be even more marked.

The shift of manufacturing to developing economies in turn changed the composition of developing country exports. Figure 5 shows the composition of developing country merchandise exports for the period 1965-1999. Between 1965 and 1980 the manufacturing share of developing country exports rose from 15 percent to approximately 27 percent. Between 1980 and 1999 it rose from approximately 27 percent to approximately 83 percent. That reversed the historic pattern of trade whereby manufactured goods flowed from industrial economies to emerging economies, and it fundamentally distinguishes the third neoliberal globalization from the two earlier globalizations.

\section{THEORIZING THE THREE GLOBALIZATIONS: THREE THEORIES FOR THREE GLOBALIZATIONS}

The three globalizations each constitute a distinct separate phenomenon with different empirical characteristics, and each calls for a different theorizing. Recognizing that has radical implications.

Trade is involved in all three globalizations. However, whereas the economics of trade explains the first two globalizations, the third globalization is explained by the industrial strategy of corporations in developed economies. Conventional two-way trade was the essence of the first two globalizations, but trade has been derivative in the third globalization in the sense 
that it has been a vehicle for another strategic purpose. In the third globalization, the increase in trade and the change in the geographic composition of trade have both been driven by strategic industrial reorganization, rather than conventional mutually beneficial exchange theory.

\subsection{Absolute advantage and bridge economics: theorizing the Victorian first globalization}

The Victorian first globalization (1870-1914) is best explained by differences in production efficiency regarding agricultural products. The theory of absolute advantage gives a compelling and comprehensive explanation. How it worked is illustrated by Table 3, which shows a hypothetical matrix of output per unit of labor for manufacturing and agriculture. In manufacturing, Western Europe is shown as five times as efficient as the temperate zone emerging economies, while in agriculture the latter are three times as efficient. These patterns of relative efficiency ensured that Western Europe was competitively dominant in manufacturing, while the temperate zone emerging economies were competitively dominant in many agricultural products. Western Europe therefore exported manufactured goods to the temperate zone emerging economies, and they exported agricultural products to Western Europe.

Technological innovation was also critical to the first globalization, particularly regarding transportation costs and refrigeration. Advances in steam engine technology contributed to a shipping and railroad revolution that lowered transport costs and shortened transport times. In conjunction with that, the introduction of refrigeration technology enabled the long-distance transport of perishable products. These technological innovations constituted a form of 'bridge' economics that dramatically strengthened the links between the advanced and emerging temperate zone economies, reinforcing the economic logic of trade.

The resulting reconfiguration of the global economy yielded significant benefits. In Western Europe, cheaper agricultural products lowered the price of food, while manufactured exports increased industrial demand for labor. Western European workers therefore gained directly via increased purchasing power of wages, and indirectly via increased demand for labor that raised wages. The losers were in the agricultural sector, with land-owners suffering large losses of rent and agricultural workers facing reduced labor demand that lowered their wages.

That pattern explains why the Victorian first globalization was less endorsed in continental Europe where the agricultural sector was larger and the industrial sector smaller, so that political opposition was larger and political support smaller. In contrast, the UK endorsed the shift, with the great political watershed being the Importation Act of 1846 which repealed the Corn Law tariffs and import restrictions. The effect of repeal of the Corn Laws is captured in Figure 6 (overleaf), which shows how UK imports of wheat surged in the 15 years after repeal.

The temperate zone emerging economies benefitted from increased demand for agricultural products which provided income to purchase manufactures. The increased demand also promoted a flow of investment that accelerated development by contributing to

Table 3 Explaining the Victorian first globalization: a hypothetical matrix of labor productivities

\begin{tabular}{lcc}
\hline & $\begin{array}{c}\text { Manufacturing } \\
\text { Output per }\end{array}$ & $\begin{array}{c}\text { Anit of laborilture } \\
\text { Output per }\end{array}$ \\
\hline Western Europe & 5 & 1 \\
Temperate zone emerging economies & 2 & 6 \\
\hline
\end{tabular}




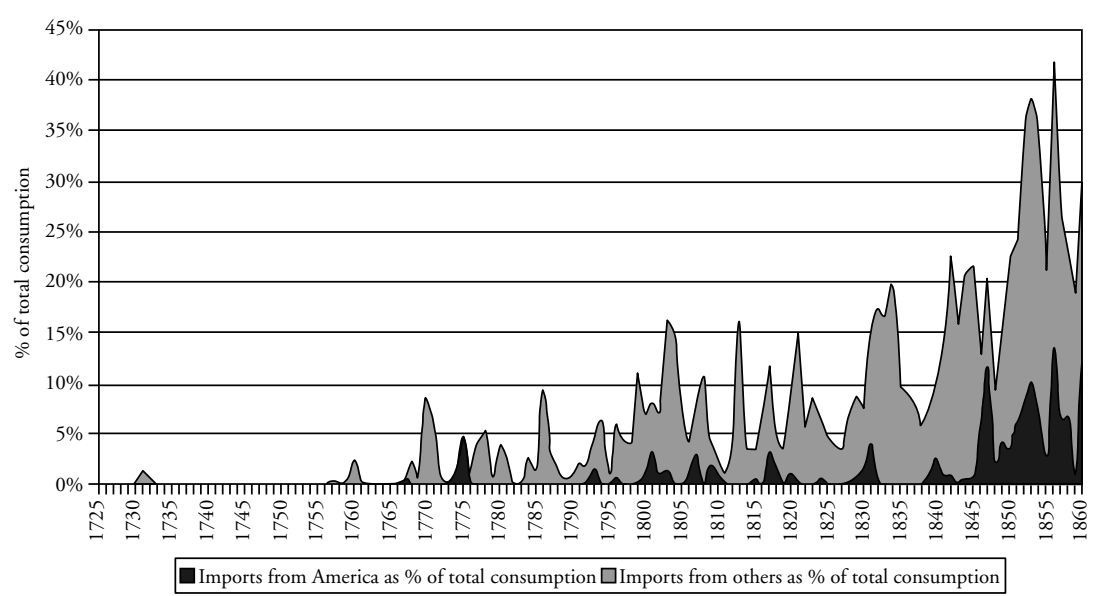

Source: Sharp (2008).

Figure 6 Imports of wheat as a percentage of UK consumption, 1725-1860

increased agricultural productivity, expanded agricultural capacity, and increased transportation connectivity with Western European markets. It also encouraged a flood of immigration. $^{2}$

However, the long-term benefits for these economies was more muted. First, increased agricultural supply later drove down agricultural prices, causing adverse secular terms-oftrade effects that lowered income. Second, countries that focused on agricultural production rather than manufacturing forewent the dynamic innovation effects that manufacturing provided. The great exception to this was the United States which benefitted from agricultural exports, while retaining high tariffs that discouraged manufacturing imports and encouraged development of domestic manufacturing.

In terms of the current debate over neoliberal globalization, there are several important takeaways from the Victorian first globalization. First, there were global gains from trade and industrial country workers shared in them.

Second, these beneficial outcomes have had an enduring shaping impact on economists' and politicians' views of trade, which continue to live on, even though they may be of no relevance in the current era. Once a point of view becomes entrenched, it becomes very difficult to overthrow, especially when it serves the interests of society's dominant elites.

Third, the Victorian globalization was driven by patterns of absolute advantage, and absolute advantage produces a production allocation that is identical to comparative advantage. That has led economists to assert that trade was driven by comparative advantage, when in fact it was driven by absolute advantage. Comparative advantage (that is, the principle of opportunity cost) is the ex post theoretical explanation of why there were gains from trade, rather than the historical explanation of why there was trade.

Fourth, the complex issue of the relation between trade and development was already present in the first globalization, with trade having both good and bad effects on emerging economies.

2. In addition to trade based on absolute advantage, there was also a politically driven colonial trade. Thus, India was deindustrialized by the British who stifled Indian textile production in order to promote imports of British textiles. 


\subsection{Scale economies and variety: theorizing the Keynesian-era second globalization}

The Keynesian-era second globalization $(1945-1990)$ is significantly explained by the theory of intra-industry trade developed by Krugman (1979). The economic logic is as follows. Trade opening expands the size of the market. That enables firms to further exploit economies of scale and lower prices, and it also enables the introduction of additional varieties that increase consumer utility.

That logic is illustrated in Figure 7, which is based on Palley (2017). The left-hand panel shows that prices are equal to a mark-up over the average cost of the representative firm, which falls as its output increases. The right-hand panel shows a positively sloped pricevariety frontier (PVF) that confronts the economy with a trade-off between lower prices and more variety. Each firm produces a single type of good. As variety increases, each firm loses market share and economies of scale, resulting in higher average costs and prices. The equilibrium depends on consumer preferences for lower prices versus more variety. ${ }^{3}$ Trade opening increases the size of the market, which shifts the PVF down. The logic is that a larger market generates lower prices for each level of variety. The shift of the PVF makes households better off since they have access to both lower prices and more variety.

In autarky, each firm produces $y_{\text {autarky }}$; the price of goods is $p_{\text {autarky }}$; and the number of variety of goods is $v_{\text {autarky }}$. With trade, each firm produces $y_{\text {trade }}$; the price of goods is $p_{\text {trade }}$; and the global number of variety of goods is $v_{\text {trade }}$. Individual firms therefore expand in size $\left(y_{\text {trade }}>y_{\text {autarky }}\right)$, which is what enables them to achieve economies of scale and charge

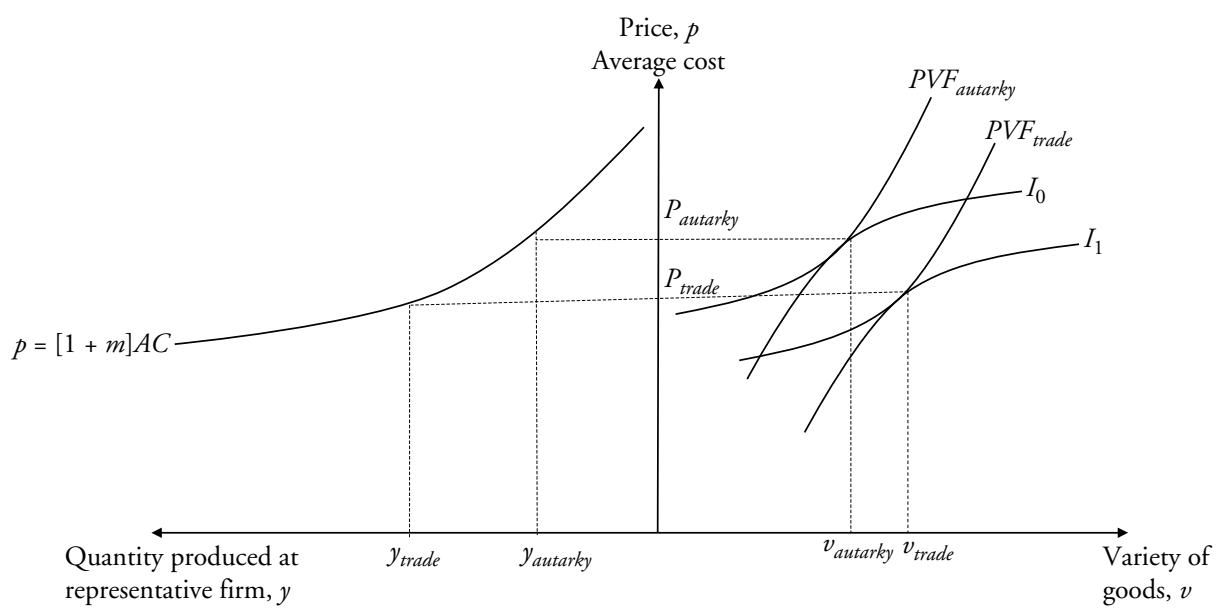

Figure 7 Explaining the Keynesian second globalization: intra-industry trade

3. Households are assumed to be identical and derive utility from consumption quantity $(c)$ and variety $(v)$ of goods. Each household consumes all goods in equal amounts. Firms have the same technology and each firm has the same mark-up. Given those assumptions, all varieties of goods have the same price $(p)$. The representative household's direct utility function is $U(c, v)$. The utility of consumption quantity is captured by the representative quantity, and the utility of variety is captured by the number of varieties. The representative household's indirect utility function is $U(p, v)$ and the utility value of consumption is captured by the representative price in the indirect utility function. The standard assumptions apply regarding diminishing marginal utility of quantity and variety, so as to yield well-behaved indifference curves as shown in Figure 6. 
lower prices $\left(p_{\text {trade }}<p_{\text {autarky }}\right)$. Assuming normal preferences (that is, both the demands for consumption and variety are normal goods), variety increases $\left(v_{\text {trade }}>v_{\text {autarky }}\right)$. However, the production of varieties is split across countries so that the number of firms in each country may fall, but each remaining firm is unambiguously larger. That is illustrated by the auto industry. Global auto trade has led to the closure of many auto producers, but those producers that remain are much larger and there is more variety within each country owing to the presence of imported varieties.

After trade opening, the mix of lower prices and increased variety will depend on consumers' preferences for lower prices (that is, increased quantity) versus additional varieties. If consumers have a strong taste for variety, then the increased size of the market will be predominantly used to support increased variety. If consumers have little taste for variety, then the increased size of the market will be predominantly used to support lower prices.

The gains to trade are further increased if competition from more firms lowers mark-ups or increases productivity. Together, these effects generate significant gains from trade. The channels are increased economies of scale, increased variety, increased productivity, and reduced mark-ups. That explains the beneficial outcomes of the General Agreement on Tariffs and Trade (GATT) trade liberalization which contributed to higher real wages, a higher wage share, and improved income distribution. ${ }^{4}$ As with the Victorian first globalization, workers benefitted from the Keynesian-era second globalization, and the latter also likely helped reduce inequality via its effect on mark-ups.

\subsection{Barge economics: theorizing the neoliberal third globalization}

Trade was the motivation and fulcrum of the Victorian and Keynesian globalizations. The former was driven by trade motivated by the international pattern of absolute advantage, while the latter was driven by intra-industry trade motivated by economies of scale and demand for variety. The neoliberal third globalization constitutes a completely different phenomenon driven by organization change. Trade is an important component because goods and services must cross international borders, but the driving motivation is industrial reorganization aimed at increasing the profitability and the profit share.

Neoliberal globalization can be described as 'barge economics' (Palley 2007; 2008). The idea draws on the observation by Jack Welch, former CEO of General Electric, that he would ideally like having 'every plant you own on a barge.' Welch envisioned factories floating between countries to take advantage of lowest costs, be they due to undervalued exchange rates, low taxes, subsidies, absence of regulation, or abundant cheap exploitable labor.

Neoliberal globalization makes 'barge economics' a reality. The barge is built on a complex of organizational and technological change that rests on a legal and policy infrastructure which supports offshoring and foreign outsourcing of production. Trade remains central because goods must cross borders, and hence the need for trade agreements. However, barge economics is fundamentally different from the conventional economics of trade. The latter is about cross-border exchange of goods and services with immobile production. The former is about creating flexible mobile international production networks configured on the principle of global cost arbitrage.

The roots of barge economics are to be found within the economics of industrial organization and the evolution of the multinational corporation (MNC), or, more generally speaking, the 'dispersed firm.' The evolution of the dispersed firm is a long-running historical narrative.

4. Interestingly, Palley (1999) reports that increased international openness reduced US income inequality (as measured by the Gini coefficient) in the period 1968-1980. 
The classic stylized Victorian manufacturing firm consisted of a factory on the ground floor, with management and the accounting department overlooking the factory floor. As firms grew in size with national economies, their core operations were gradually expanded and dispersed within the confines of the national economy. The multinational corporation represents the extension of that dispersal process into the international sphere, and it accelerated in the two decades after World War II. However, a key feature of the post-World War II multinational corporation was that its production was primarily for local markets: Ford Europe and General Motors Europe both produced for the European market and not the US market.

Neoliberal globalization changed that pattern so that foreign production of subsidiary companies (especially US firms) was increasingly targeted for export back to the home country. This change is exemplified in Mexico and China, which have become the base for MNC export production platforms. The goals behind this change in industrial organization have been increased profitability, a higher profit share, and escaping organized labor whose strength was concentrated in manufacturing.

Those motivations are completely different from conventional trade theory, which is constructed on the prospect of home country producers looking to expand their domestic production via exports. Barge economics reverses that pattern and has home country producers shrinking domestic production, shifting production facilities offshore, and then importing offshore production.

Analytically, barge economics potentially reverses all the standard welfare claims regarding the benefits of trade. Conventional trade theory approaches trade through the lens of mutually beneficial exchange. The anchoring assumption is that trade only takes place if there are mutual gains, which inclines conventional theory to find such gains, absent pathologies. In contrast, barge economics is motivated by distributional conflict. Since investments and expenses incurred over distributional conflict are costly to the economy, distributional conflict undermines claims of a market economy to be Pareto optimal. Consequently, barge economics means there may be no net gains from trade and society may even potentially be worse off. Profits increase so that capital gains and labor loses, but labor's losses may even exceed capital's gains.

Barge economics views neoliberal globalization as a form of planned technological innovation aimed at reorganizing global production. Organization is a form of technology, and barge economics promotes reorganization for the benefit of capital. This perspective connects with the work of the historian David Noble (1977) who argued that technology is chosen by corporations in the interests of owners, rather than being scientific manna from heaven.

These ideas can be illustrated in a simple partial equilibrium model with endogenous technology choice drawn from Palley (1998). The model shows how choice of technology affects income distribution, and it also shows how choice of technology can impose additional unaccounted costs via externalities. That is another feature of neoliberal globalization, albeit not the focus of the current paper.

The model is illustrated in Figure 8 (overleaf). Initially, firms are using production technology 1 which has a constant marginal product of labor $a_{1}$. Under that technology, capital receives a share $s_{1}$ and labor receives a share $\left[1-s_{1}\right]$. Additionally, the technology produces harmful pollution as a by-product, with the pollution-output coefficient being $b_{1}$. The level of demand $(D)$ is exogenously given. Firms meet that demand, employ $N_{1}{ }^{*}$ workers, produce $P_{1}^{*}$ units of pollution, and earn profits of $\pi_{1}{ }^{*}$.

Now, suppose firms can relocate production offshore and produce there, using production technology 2. The new technology has a marginal product of labor $a_{2}$, a pollutionoutput coefficient of $b_{2}$, and capital receives $s_{2}$. The new technology is strictly less 


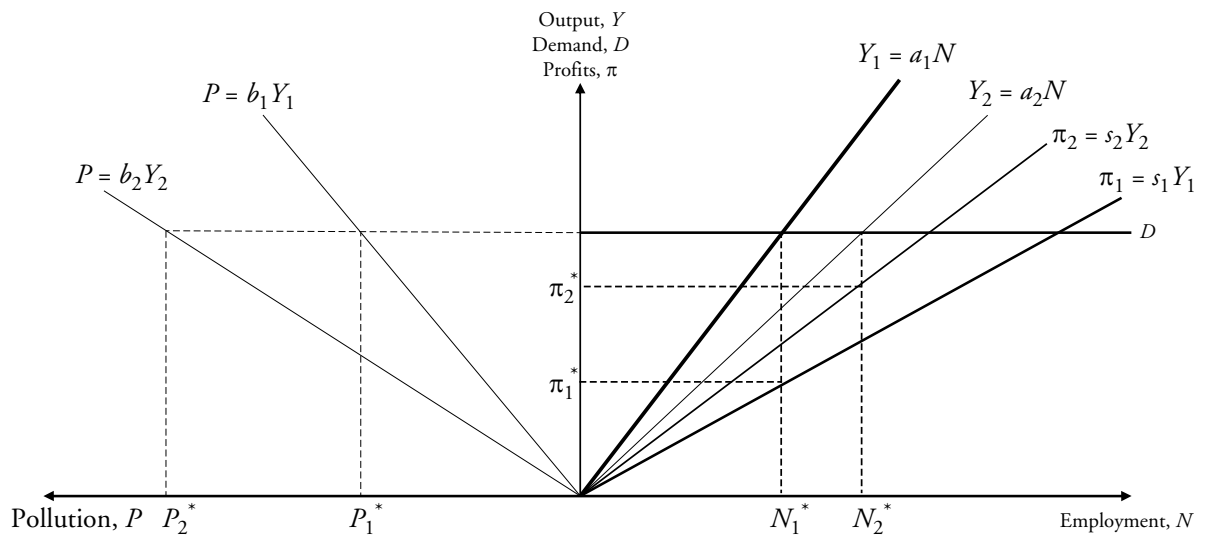

Figure 8 A simple partial equilibrium model illustrating barge economics

productive $\left(a_{2}<a_{1}\right)$ and strictly more polluting $\left(b_{2}>b_{1}\right)$. Despite that, firms have an incentive to adopt it because it is more profitable at all output levels. Consequently, they will shutter domestic production and produce offshore.

If demand is unchanged, firms will continue to produce $D$ and will supply the domestic markets with imports. They will employ $N_{2}{ }^{*}$ workers, produce $P_{2}{ }^{*}$ units of pollution, and earn profits of $\pi_{2}{ }^{*}$. At the partial equilibrium level, global output is unchanged; home country output and employment fall; foreign country output and employment increase; global employment increases; global pollution increases; the global profit share increases; and the global labor share decreases. Home country labor loses and the home economy shrinks.

At the general equilibrium level, the effects depend on what happens to demand and what happens to displaced workers. If demand falls, then global output can contract. If laid-off home country workers are re-employed, home country output recovers somewhat, with the extent of the recovery depending on their productivity in their new jobs. If newly employed foreign country workers change jobs, the increase in foreign country output is mitigated, with the extent of mitigation depending on their productivity in their prior jobs.

The dynamic implications of barge economics may be even worse. Manufacturing is the sector identified with offshoring. If manufacturing is the source of dynamic economies of scale (that is, faster productivity growth), then the home country may lose even more. Likewise, if manufacturing is the main driver of investment, a smaller manufacturing sector will result in less capital accumulation and lower growth. Ironically, barge economics may reverse the asymmetry of the first globalization in which emerging economies specialized in the less dynamic agriculture sector rather than manufacturing.

Worse yet, barge economics changes the character of the competitive process governing the global economy, giving rise to adverse dynamics that are permanently entrenched. Conventional trade theory views trade through the lens of static allocation. Trade supposedly reallocates global production in ways that increase overall production, thereby potentially making everyone better off. Barge economics is about process, not just static allocation. It promotes race-to-the-bottom dynamics, the adverse consequences of which persist and compound over time. Such a 'process' view of trade is completely absent in conventional theory, which explains the analytical gulf between conventional economists and lay critics of neoliberal globalization. 
Lastly, there may be adverse impacts on the political equilibrium that cause changes in other economic policies in ways which further increase the profit share and lower the wage share (Acemoglu/Robinson 2013; Palley 2017/2018). One such impact may be via the effect of money on politics. Increasing the profit share and lowering the wage share increases the political power of capital. A second impact may be via union density. Manufacturing has historically been the most unionized sector, so that closing factories lowers union density, causing further reductions in the wage share owing to loss of worker bargaining power. Additionally, declining union density negatively impacts the political power of labor, again to the benefit of capital's political power.

The new logic of barge economics is clearly visible in the changed nature of the trade policy debate. Under the GATT process, which ended with the 1979 Tokyo round, trade policy aimed at reducing tariffs and quotas. The goal was to facilitate international exchange of goods. Since then, so-called trade agreements have increasingly been concerned with globally standardizing intellectual property rights (that is, copyrights and patents), giving foreign investors special protections via extra-legal investor-state dispute settlement mechanisms, opening government procurement to foreign competition, and limiting governments' abilities to pursue industrial policy. Side by side, the critics have argued for global labor and environmental standards. The policy focus has shifted from trade to facilitating corporations to reorganize the global structure of production, with critics defensively trying to place limits on corporations' ability to restructure production without regard for social standards.

The supporting evidence for barge economics comes from multiple sources. Earlier, Table 2 showed the massive increase in developing and transition economies' share of global GDP and global exports after 1990; Figure 4 showed how the distribution of world manufacturing shifted to developing country economies in the period after 1980; and Figure 5 showed how the composition of developing country merchandise exports changed after 1990, becoming dominated by manufactured goods.

Table 4 shows the changing pattern of inward foreign direct investment (FDI), which has increasingly flowed to developing countries. In 1980, the developing and transition economy share of global FDI was 13.6 percent. By 2010, it had risen to 49.6 percent.

Table 5 shows the ownership composition of Chinese exports and imports in 2005. Foreign-owned subsidiaries supplied 50.4 percent of China's exports, and a further 26.3 percent were supplied by joint ventures. That means foreign capital was associated with the supply of 76.7 percent of Chinese exports.

Table 4 Developing and transition economies' share of global foreign direct investment (FDI), 1980-2015

\begin{tabular}{lcccccc}
\hline & 1980 & 1990 & 2000 & 2005 & 2010 & 2015 \\
\hline Share of global FDI (\%) & 13.6 & 16.9 & 17.5 & 38.1 & 49.6 & 45.4 \\
\hline
\end{tabular}

Source: UNCTAD (2016: table 6.2).

Table 5 Decomposition by firm ownership structure of Chinese exports and imports in 2005 All firms State-owned Private domestic Joint ventures Foreign-owned

\begin{tabular}{llrrrr}
\hline Exports & $100 \%$ & 10.3 & 13.1 & 26.3 & 50.4 \\
Imports & $100 \%$ & 21.7 & 7.1 & 24.1 & 47.2 \\
\hline
\end{tabular}

Source: Manova/Zhang (2008). 


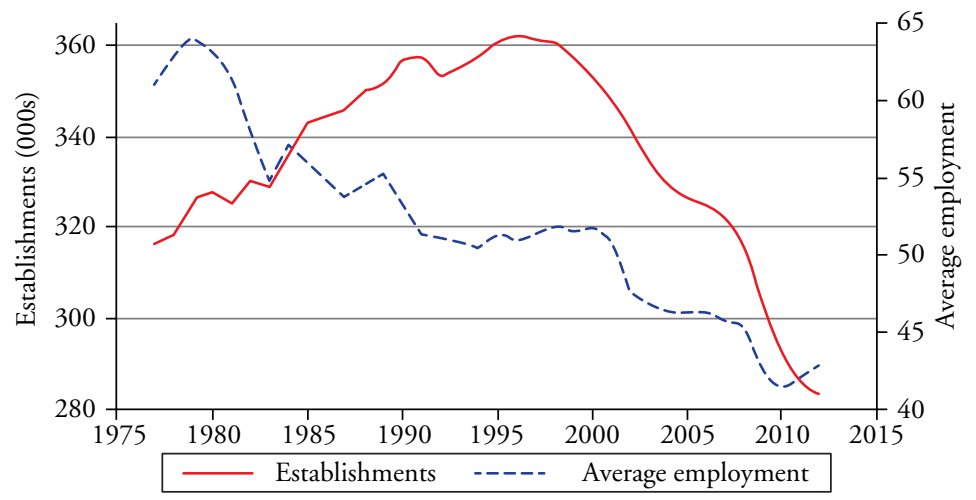

Source: Fort et al. (2018).

Figure 9 US manufacturing establishments and average employment, 1977-2012

Another fragment of evidence comes from factory closures in the US, which have been the other side of investing in new offshore production facilities. Figure 9 shows the number of US manufacturing establishments and average establishment employment over the period 1977-2012. The number of establishments trended upward through to 1996, two years after the inauguration of NAFTA. Thereafter, the number of establishments started declining despite the fact that the economy was booming. China PNTR (permanent normal trade relations) was inaugurated in 2000 and China joined the World Trade Organization (WTO) in 2001, and the number of establishments then fell throughout the business cycle expansion of 2001-2007. Average establishment employment size fell throughout the period, which is consistent with steady labor productivity improvement. However, the abrupt reversal of trend and the collapse in the number of establishments is consistent with the neoliberal third-globalization hypothesis.

A final piece of evidence consistent with barge economics is the US goods trade deficit. Barge economics predicts a structural increase in the trade deficit since manufacturing production is offshored and then imported into the economy in place of previously produced domestic goods. Table 6 shows the US trade deficit by business cycle peak year from 1960 to 2007,

Table 6 The US goods and services trade deficit by business cycle peaks, 1960-2007

\begin{tabular}{lccc}
\hline Peak year & Trade deficit $(\$$ millions) & GDP $(\$$ billions $)$ & Trade deficit/GDP (\%) \\
\hline 1960 & 3508 & 526.4 & 0.7 \\
1969 & 91 & 984.6 & 0.0 \\
1973 & 1900 & 1382.7 & 0.1 \\
1980 & -25500 & 2789.5 & -0.9 \\
1981 & -28023 & 3128.4 & -0.9 \\
1990 & -111037 & 5803.1 & -1.9 \\
2001 & -429519 & 10128.0 & -4.2 \\
2007 & -819373 & 13807.5 & -5.9 \\
\hline
\end{tabular}

Sources: Economic Report of the President (2009) (URL: https://www.gpo.gov/fdsys/pkg/ERP2009/pdf/ERP-2009.pdf) and author's calculations. 
with peak year selection serving as a control for cyclical effects. The table shows there was a slow trend deterioration in the trade deficit through to 1990, but thereafter the deterioration accelerates dramatically as predicted by barge economics.

Lastly, barge economics explains the supposed conundrum of why capital flows north (Palley 2014; 2015). The explanation is simple. The US trade deficit is the twin of the trade surpluses of China and East Asia. Barge economics creates that pattern of deficits and surpluses by having corporations relocate production to emerging markets, and those countries now host the export production platforms that supply multinational home countries.

\section{MORE ON BARGE ECONOMICS: PHANTOM TRADE AND POLICY IMPLICATIONS}

Barge economics is about the implications of the increased ability of corporations to shift production between countries with ease and little cost. The purpose of these shifts is to redistribute income. Accompanying effects can include the introduction of production inefficiencies, negative externalities, and diminished global demand.

Another important feature of barge economics can be termed 'phantom' trade. That is, trade which is implicitly present but does not actually occur. In conventional trade theory, trade is about reaping the efficiency benefits from reorganization of global production, and actual trade is necessary to reap those benefits. In barge economics, actual trade is not necessary to deliver corporate goals. All that is needed is the 'threat' of trade, which corporations can use to impose income redistribution. This trade threat effect can be termed 'phantom trade,' capturing the notion that trade is present even though it does not occur. Such phantom trade has been clearly documented by Bronfenbrenner (2000) and Bronfenbrenner/Luce (2004), who provide evidence showing how NAFTA was used to force concession bargaining in US manufacturing in the late 1990s and early 2000s.

Phantom barge trade has slightly different effects from actual barge trade because production does not move. It redistributes income, but it does not cause production inefficiencies or negative externalities. Global demand falls if the propensity to save out of profit exceeds the propensity to save out of wages, which is the standard assumption in Kaleckian macroeconomics. ${ }^{5}$

Barge economics also has important political economy and policy implications. As noted above, barge economics inevitably produces trade deficits. That follows from the logic of production reorganization aimed at securing income redistribution, rather than a balanced reorganization of global production as in conventional trade theory. Production is moved to developing countries so that they increase exports, but there is no compensating rearrangement of production to ensure an offsetting increase in developed country net exports.

As long as economists are in denial of that, it will result in twisted explanations which blame persistent trade deficits on either excessive budget deficits or inadequate private saving. Those explanations can then be invoked to justify austerity policies aimed at reducing budget deficits, or to justify policies aimed at increasing saving which tend to also increase income inequality. Misunderstanding of the trade deficit implications of barge economics can

5. The fall in demand will be diminished if some of the cost savings are passed on to buyers in the form of lower prices. As regards trade effects, that will tend to increase exports and diminish imports. It also matters how labor benefit concessions are delivered. If concessions are via lowered nominal wages, that may have adverse debt-deflation effects on aggregate demand. If they are via reduced fringe benefits (health and pension benefits), that will produce pure income redistribution. 
therefore have significant knock-on impacts on economic policy and politics, which in turn impact income distribution.

\section{CONCLUDING OBSERVATIONS}

An examination of the history of globalization argues for there being three distinct globalizations: the Victorian first globalization; the Keynesian-era second globalization; and the neoliberal third globalization. The first two globalizations are fundamentally different from the third. The former two were about reaping the benefits of trade, while the latter has been about reorganizing the structure of global production so as to increase capital's share.

Barge economics provides a theoretical explanation of the neoliberal third globalization that is consistent with all the stylized facts. These include the changed pattern of FDI flows; deindustrialization in the developed economies; the evolution of the US trade deficit; and the global imbalance conundrum which has capital flowing north.

A three-globalizations perspective exposes the ideological foundations of mainstream trade teaching. Trade has never been principally driven by either comparative advantage or cross-country differences in capital-labor endowment ratios. The first globalization was driven by patterns of absolute advantage related to the history of industrialization in the north and climatic conditions in the temperate zone emerging economies. The second globalization was driven by economies of scale and consumer demand for variety. The Heckscher-Ohlin trade model has never explained the bulk of trade, which explains why it has been so hard to find the model's predictions in the data (Leontieff 1953).

Ironically, barge economics may have created a world that resembles Heckscher-Ohlin, but it is only a superficial resemblance. Third-globalization trade has not been structured around factor ratio differences. Instead, it has been driven by corporate restructuring of global production which has shipped capital, technology, and know-how to emerging economies. Additionally, barge economics produces income redistributions that look like Stolper-Samuelson (1941) effects, but they are not the same. The latter are generated in the context of Heckscher-Ohlin trade which increases global productivity, whereas that is not so with barge economics.

A three-globalizations perspective also rationalizes the ambivalence of Keynesians and post-Keynesians regarding trade. At the microeconomic level, trade was mutually beneficial in the first and second globalizations. Yet at the macroeconomic level, trade always had the potential to create problems by being a drain of aggregate demand. However, it was not trade per se that was the problem, but rather the failure to pursue internationally coordinated aggregate demand management in the context of optimally designed international adjustment rules. Given that failure, it was reasonable for Keynesians to want trade restrictions, but that was a second-best policy response to macroeconomic policy failures. The neoliberal third globalization upends that assessment. Now, trade can be damaging at the microeconomic level so that there are both microeconomic and macroeconomic reasons for carefully managing trade. Trade is the canal through which the barge moves.

Looking to the future, world trade as a share of global GDP fell sharply with the onset of the Great Recession of 2008, then recovered its previous level of approximately 60 percent by 2011, and has since fallen slightly as global trade has grown slower than global GDP. That suggests neoliberal globalization has leveled off, as measured by trade. However, 'leveling off should not be confused with 'ended.' Barge economics is here to stay, with its attendant implications for potential productive inefficiency, redistribution of income from labor to capital, and race-to-the bottom dynamics. 
Lastly, there are two important political implications. First, there are different types of trade and they coexist. Some trade is good, and some bad. That makes trade policy very difficult, as encouraging the good may also encourage the bad, and filtering out the bad may also filter out the good. Second, as long as neoliberal globalization is viewed through the lens of conventional trade theory, confronting the adverse consequences of barge economics will be more difficult. That is because the case for restricting barge economics will be opposed by the tyranny of stylized history which describes neoliberal globalization as just a further deepening of mutually beneficial trade.

\section{REFERENCES}

Acemoglu, D., Robinson, J.A. (2013): Economics versus politics: pitfalls of policy advice, in: Journal of Economic Perspectives, 27(2), 173-192.

Allen, R.C. (2011): Global Economic History: A Very Short Introduction, Oxford: Oxford University Press.

Autor, D.H., Dorn, D., Hanson, G.H. (2013): The China Syndrome: local labor market effects of import competition in the United States, in: American Economic Review, 103(6), 2121-2168.

Bronfenbrenner, K. (2000): Uneasy terrain: the impact of capital mobility on workers, wages, and union organizing, Report prepared for the United States Trade Deficit Review Commission, Washington, DC, September.

Bronfenbrenner, K., Luce, S. (2004): The changing nature of corporate global restructuring: the impact of production shifts on jobs in the U.S., China, and around the globe, Report prepared for the U.S.-China Economic and Security Review Commission, Washington, DC, October.

Fort, T.C., Pierce, J.R., Schott, P.K. (2018): New perspectives on the decline of U.S. manufacturing employment, NBER Working Paper 24490, National Bureau of Economic Research, Cambridge, MA, April.

Klasing, M.J., Milionis, P. (2014): Quantifying the evolution of world trade, 1870-1949, in: Journal of International Economics, 92, 185-197.

Krugman, P. (1979): Increasing returns, monopolistic competition, and international trade, in: Journal of International Economics, 9(4), 469-479.

Leontieff, W. (1953): Domestic production and foreign trade: the American capital position re-examined, in: Journal of the American Philosophical Society, 97(4), 332-349.

Manova, K., Zhang, Z. (2008): China's Exporters and Importers: Firms, Products, and Trade Partners, Unpublished manuscript, Department of Economics, Stanford University, CA, June.

Martin, W. (2001): Trade policies, developing countries, and globalization, Development Research Group, World Bank, Washington, DC, October.

Melitz, M.J., Trefler, D. (2012): Gains from trade when firms matter, in: Journal of Economic Perspectives, 26(2), 91-118.

Noble, D. (1977): America by Design: Science, Technology, and the Rise of Corporate Capitalism, New York: Knopf.

Ortiz-Ospina, E., Roser, M. (2017): International trade, Published online at OurWorldInData.org.

Palley, T.I. (1998): Macroeconomics with conflict and income distribution, in: Review of Political Economy, 10, 329-342.

Palley, T.I. (1999): Manufacturing matters: the impact on productivity growth, wages, and income distribution, Economic Policy Paper E35, AFL-CIO Public Policy Department, Washington, DC.

Palley, T.I. (2007): Jack Welch's barge: the new economics of trade, Alternet.com, October 1.

Palley, T.I. (2008): Barge economics: the new economics of globalization, Written testimony to the Subcommittee on Investigations and Oversight, House Committee on Science and Technology, US Congress, Tuesday, June 24, URL: https://science.house.gov/sites/republicans.science.house. gov/files/documents/hearings/062408_palley.pdf.

Palley, T.I. (2012): From Financial Crisis to Stagnation: The Destruction of Shared Prosperity and the Role of Economics, Cambridge, UK: Cambridge University Press. 
192 European Journal of Economics and Economic Policies: Intervention, Vol. 15 No. 2

Palley, T.I. (2014): Global imbalances: benign by-product of global development or toxic consequence of corporate globalization?, in: European Journal of Economics and Economic Policies, 11(1), 1-19.

Palley, T.I. (2015): The theory of global imbalances: mainstream economics vs. structural Keynesianism, in: Review of Keynesian Economics, 3(1), 45-62.

Palley, T.I. (2017): The Economics of Intra-Industry Trade: A New Model, Unpublished manuscript.

Palley, T.I. (2017/2018): A theory of economic policy lock-in and lock-out via hysteresis: rethinking economists' approach to economic policy, in: Economics: The Open-Access, Open-Assessment E-Journal, 11, 1-18.

Sharp, P. (2008): The long American grain invasion of Britain: market integration and the wheat trade between North America and Britain from the 18th century, Discussion Paper 08-20, Department of Economics, University of Copenhagen, Denmark.

Stolper, W.F., Samuelson, P.A. (1941): Protection and real wages, in: Review of Economic Studies, 9(November), 58-73.

UNCTAD (2016): UNCTAD Handbook of Statistics 2016, New York: United Nations.

WTO (2013): World Trade Report, 2013: Factors Shaping the Future of World Trade, Geneva: World Trade Organization. 